\title{
MITOS MASKULINITAS SEBAGAI KONSEP KONTEN PRODUK KECAP ABC DI MEDIA SOSIAL INSTAGRAM (Studi Kasus: Konten "Akademi Suami Sejati")
}

\author{
1Andika Indrayana, 2Nurmala Putri Mardianti \\ Program Studi Desain Komunikasi Visual \\ Fakultas Seni Rupa Institut Seni Indonesia Yogyakarta \\ 1andikaindrayana@gmail.com, 2nrmalaputri@gmail.com
}

\begin{abstract}
Akademi Suami Sejati is a part of the theme used by Kecap ABC in their commercial campaign on Instagram. The theme aims at promoting gender equality in domestic field illustrated by a husband contributing in the household cooking activity as a means to build harmony. By means of this theme, diverse masculine images are represented using visual languages in many contents.

This research objective was to identify and interprete the myth of masculinity in the Instagram content to get the structures of and relation between the myths and gender discourses. Roland Barthes' theory on signs levels and his seven methods of interpretation were employed in studying the visual objects identified.

The research showed that: 1) the masculine images represented the idea of gender equality without demeaning men's image of masculinity. 2) masculine image is identical to the Javanese concept 'dadi wong' (becoming a gentleman) and 'dadi modern' (becoming a modern man) in Javanese culture perspective.
\end{abstract}

Keywords: Myth, Instagram Content, Masculinity, Gender Equality

Relevance to Visual Comunication Design Practice: This research can be used as paradigm to create myth of masculinity in visual communication design's project.

\section{LATAR BELAKANG MASALAH}

Penggunaan konten sebagai alat pemasaran (content marketing) suatu produk, saat ini menjadi salah satu strategi yang banyak digunakan oleh sebuah brand untuk membangun kedekatan personal dengan audiens maupun konsumen. Sebuah studi yang dilakukan Content Marketing Institute dan MarketingProfs mengungkapkan bahwa $76 \%$ perusahaan bisnis-ke-konsumen (B2C) dan $88 \%$ perusahaan bisnis-ke-bisnis (B2B) di Amerika Utara menggunakan pemasaran konten pada 2016. (Kotler, dkk. 2019: 120).

Pemasaran konten pada saat ini merupakan bentuk perubahan dalam aktivitas promosi, di mana popularitas konten pada iklan tradisional sudah mulai menurun.
Konten iklan di media tradisional dianggap mengganggu, menginterupsi, hingga terlalu berlebihan dalam menyampaikan pesan. Keberadaan new media, terutama internet dengan berbagai produk turunannya seperti website, media sosial, hingga aplikasi (apps), saat ini mulai mengubah strategi promosi. Pemasaran konten menggeser peran pemasar, dari promotor merek menjadi pencerita. (Kotler, dkk. 2019: 119).

Pemasaran berbasis konten saat ini dapat terlihat dari berbagai media sosial yang digunakan oleh brand, di mana konten yang terdapat di dalamnya seringkali bukan hanya berisi tentang promosi produk atau beriklan, tetapi juga menampilkan beragam konten lain yang tidak berkaitan dengan promosi produk 
secara langsung, tetapi dengan format seperti acara, tips dan trik dari sumber lain yang diolah kembali oleh brand, hingga unggahankembali (repost) dari unggahan konsumen. Kesemuanya merupakan cara baru sebuah brand untuk membangun kedekatan personal dengan audiens atau konsumen secara menarik, kreatif hingga kolaboratif.

Produk penyedap makanan merek Kecap ABC merupakan salah satu produk yang menggunakan berbagai media untuk menyebarkan beragam konten dengan tematema tertentu. Dari observasi yang dilakukan, media dan tema konten yang digunakan antara lain:

1. Website, dengan nama URL: www.heinzabc.co.id.

Tema konten yang tampak digunakan pada laman website resminya adalah "Akademi Suami Sejati". Hal tersebut dapat terlihat dari adanya logo tema yang terdapat pada halaman utama.

2. Media sosial Instagram dengan nama akun: kecapabcid.

Pada media ini, sebagian besar unggahan bertema: Akademi Suami Sejati, Eksploresep, dan Resep Perasan Pertama. Hal tersebut dapat dilihat dari penggunaan logo dan tagar yang terdapat pada tiap konten.

3. Media sosial Facebook dengan nama akun: Kecap ABC

Pada media ini, sebagian besar konten bertema: Akademi Suami Sejati, Eksploresep dan Resep Perasan Pertama.

4. Media sosial YouTube dengan nama akun: HeinzABC

Pada media ini, sebagian besar konten bertema: Akademi Suami Sejati, Eksploresep by Kecap ABC, ABC Pedasnya Indonesia, World's Spiciest
Noodles by Sambal ABC, Resep Perasan Pertama Kecap ABC, ABC Kacang Hijau dan Tantangan Sambal ABC.

Tema "Akademi Suami Sejati" merupakan salah satu tema yang banyak mengemas maskulinitas melalui visual kontennya, baik dalam wujud gambar maupun video. Sosok laki-laki tampak 'diciptakan' agar memiliki peran di ruang domestik, khususnya dapur sebagai wujud kesetaraan. Melalui berbagai kontennya, lakilaki masa kini, terutama suami, diposisikan, diajak, dan dipengaruhi agar menjadi figur yang tidak hanya berperan mencari nafkah dengan bekerja di luar rumah, tetapi juga harus mampu membangun kesetaraan dengan perempuan (istri) dalam aktivitas rumah tangga, salah satunya adalah perannya di dapur, yaitu memasak. Ruang domestik secara umum selalu identik dengan kaum perempuan, dan laki-laki modern berada di wilayah publik. Namun demikian, produk Kecap ABC melalui tema Akademi Suami Sejati mencoba untuk mengubah paradigma tersebut.

Visualisasi konten dengan tema “Akademi Suami Sejati”, baik melalui elemen visual maupun verbal, dapat ditinjau sebagai wujud perubahan ideologi gender, yang ketika didistribusikan melalui media, tidak hanya berfungsi membangun citra atau positioning produk kecap $\mathrm{ABC}$ di mata audiens semata, tetapi juga upaya menyebarkan mitos mengenai maskulinitas, sehingga memungkinkan terjadinya perubahan ideologi gender.

Mitos mengenai laki-laki memasak, dengan berbagai atributnya seperti penggunaan celemek, menggunakan alat-alat memasak, pengetahuan akan bumbu atau resep, pada dasarnya telah menjadi mitos 
yang umum diketahui oleh masyarakat, seperti seorang koki di hotel hingga penjual makanan. Namun berbeda ketika aktivitas memasak adalah di ruang domestik, yang secara umum banyak dilakukan oleh perempuan, dan seringkali dianggap 'tabu' oleh budaya tertentu apabila dilakukan oleh laki-laki/suami. Di sini, konten produk kecap $\mathrm{ABC}$ berupaya untuk membangun pesan mengenai kesetaraan gender, terutama untuk konsumen atau audiens yang sudah menikah atau berkeluarga.

Berdasarkan permasalahan di atas, maka penelitian mengenai konstruksi imej maskulin yang terdapat pada konten di akun Instagram produk Kecap ABC merupakan topik yang menarik untuk diteliti, terutama untuk mengidentifikasi struktur mitos pada konten, hingga persoalan media yang dapat menyebarkan perubahan mitos mengenai ideologi gender di masyarakat.

\section{MITOS}

Mitos bagi banyak teoris maupun masyarakat, seringkali diartikan sebagai cerita (story) (Segal, 2004: 5). Dalam dictionary.com, mitos setidaknya memiliki lima definisi, yaitu: (1) Mitos adalah cerita di mana suatu budaya menjelaskan dan memahami beberapa aspek tentang realitas atau alam. (2) Mitos merupakan cerita atau hal-hal penting yang terkait di dalamnya. (3) Mitos merupakan cerita, ide atau konsep yang diciptakan (invented) oleh manusia. (4) Mitos merupakan cerita imajinatif atau fiktif terkait dengan sesuatu (things) atau manusia, dan (5) Mitos adalah cerita yang tidak memiliki bukti atau kepercayaan yang salah (false collective belief) yang digunakan oleh institusi sosial sebagai bentuk pembenaran mengenai sesuatu. (www.dictionary.com, diakses Oktober 2019). Dalam pandangan Barthes
(2009: 151) mitos adalah tipe wicara atau cara menceritakan sesuatu.

Mitos merupakan sistem komunikasi yang dapat dikatakan pula sebagai pesan. Segala sesuatu dapat menjadi mitos asalkan disajikan oleh sebuah wacana. Mitos tidak ditentukan oleh objek pesannya, tetapi oleh cara dia mengutarakan pesan itu sendiri. Dalam hal ini, proses penafsiran suatu tanda dapat dikatakan sebagai proses untuk mengurai pengutaraan pesan-pesan yang terdapat pada objek, sehingga diperoleh suatu gagasan atau ide mengenai pesan tersebut. Proses penguraian atau penafsiran mitos selalu dipengaruhi oleh sejarah, baik pengalaman manusia secara individu maupun sebagai makhluk sosial. Menurut Danesi (2010: 207), mitos dikaji untuk mempelajari bagaimana orang-orang mengembangkan suatu sistem sosial khusus dengan banyak adat istiadat dan cara hidup, dan juga memahami secara lebih baik nilai-nilai yang mengikat para anggota masyarakat untuk menjadi satu kelompok. Sebagian kalangan pemikir menyatakan, bahwa setiap usaha manusia membongkat mitos akhirnya terjebak atau melahirkan mitos baru. (Hermawan, 2016: 91)

Secara semiotik, sistem pemaknaan tataran kedua dapat dilihat dari tingkatan tanda. Dalam pandangan Barthes, sebuah tanda dapat menciptakan makna denotatif dan konotatif. Ketika makna denotatif dapat menciptakan makna konotatif yaitu makna yang lebih luas dari makna apa adanya, maka suatu tanda pada akhirnya akan menciptakan penanda konotatif, di mana makna tersebut dipengaruhi oleh mitos dan ideologi yang berkembang mengenai penanda tersebut di suatu ruang sosial dan budaya. Konotasi, identik dengan operasi ideologi, yang disebutnya 'mitos', dan berfungsi untuk 
mengungkapkan dan memberikan pembenaran bagi nilai-nilai dominan yang berlaku dalam suatu periode tertentu. (Budiman dalam Sobur, 2006: 71). Dalam hal ini, mitos dibangun oleh suatu rantai pemaknaan yang telah ada sebelumnya atau, dengan kata lain, mitos adalah juga suatu sistem pemaknaan tataran kedua. (Sobur, 2006: 71). Struktur penandaan menurut Roland Barthes dapat dijelaskan melalui gambar berikut:

Tabel 1 Struktur penandaan versi Roland Barthes

\begin{tabular}{|c|c|}
\hline $\begin{array}{c}\text { Signifier } \\
\text { (Penanda) }\end{array}$ & $\begin{array}{c}\text { Signified } \\
\text { (Petanda) }\end{array}$ \\
\cline { 1 - 1 } Tanda Denotatif (denotative sign) \\
\cline { 1 - 1 } Penanda konotatif (connotative \\
signifier) & $\begin{array}{c}\text { Petanda konotatif } \\
\text { (connotative } \\
\text { signified) }\end{array}$ \\
\hline \multicolumn{2}{|c|}{ Tanda konotatif (connotative sign) } \\
\hline
\end{tabular}

Sumber: Alex Sobur, Semiotika Komunikasi, 2006

Suatu makna konotatif yang menghasilkan mitos, menurut Barthes dapat terjadi karena tiga aspek, yaitu perseptif, kognitif, dan etis. Konotatif perseptif yaitu makna yang terjadi dari hipotesis penafsir. Makna yang muncul terhadap sesuatu selalu bersifat historis; artinya, penafsiran bergantung pada 'pengetahuan' pembaca, meskipun seolah-olah penafsiran hanya persoalan bahawa tuturan sehari-hari (langue) semata, yang hanya dapat dimengerti jika orang telah paham dengan tanda. Penafsiran jenis ini, dapat dikatakan bersifat individual dan bukan sosial, yang dapat tercipta karena faktor-faktor internal seperti pengalaman, emosi, maupun perasaan tertentu. Konotatif kognitif, sebaliknya, bersifat sosio-kultural karena muncul dari pengetahuan seseorang mengenai sesuatu. Sebagai contoh, ketika melihat foto seseorang memakai pakaian jas, maka dapat memunculkan kesan-kesan seperti eksekutif, keren, baju mahal dan sebagainya.

Baik konotasi perseptif (konotasi berdasarkan hipotesis) maupun konotasi kognitif (konotasi berdasarkan pengetahuan pembaca) menyisakan persoalan ideologis (dalam pengertian luas). Kekurangan ini dilengkapi oleh mode konotasi ketiga, yakni konotasi etis, yakni menggunakan pertimbangan atau nilai-nilai tertentu ketika melakukan baca-tafsir imaji (Barthes, 2010: 16).

Barthes mengartikan mitos secara amat luas: "segalanya dapat menjadi mitos asalkan ia diungkapkan melalui suatu wacana". Segala yang diwacanakan bisa menjadi mitos. Apa yang dimaksud Barthes dengan "wacana" juga sangat luas, tidak hanya tuturan lisan atau tertulis, tetapi juga lukisan, musik, foto, video, dan segala bentuk sarana komunikasi. (Suryajaya, 2016: 742). Di sini dapat diasumsikan, bahwa ketika sesuatu telah diwacanakan sebelumnya di ruang kultural, maka sesuatu tersebut dapat dipahami sebagai mitos. Sebagai contoh, ketika mobil diasosiasikan dengan wujud kesuksesan. Asosiasi yang muncul dari kedua hal tersebut tidak datang secara tiba-tiba, tetapi telah melalui proses pewacanaan terlebih dahulu.

\section{Penafsiran Mitos Pada Objek Fotografi}

Dalam menafsirkan objek fotografi secara konotatif, di mana suatu objek dianggap memiliki makna khusus, Barthes (2010: 6-12) memberikan enam cara, yaitu: (1) Efek tiruan. Cara ini digunakan untuk 
mengurai makna-makna konotatif yang banyak digunakan dalam fotografi. Dalam proses produksi, fotografi seringkali dibuat dengan berbagai teknik sehingga pembaca cenderung memahaminya secara denotatif atau apa adanya, padahal, di dalam sebuah foto, sebenarnya sarat dengan muatan konotatif, yang mengganti secara sempurna selubung 'objektif' denotasi. Dalam objek komunikasi visual, 'selubung' konotatif tersebut dapat muncul dari kombinasi antara tanda visual dan verbal. (2) Pose atau sikap. Sebuah iklan atau konten yang didistribusikan sebagai media promosi selalu dirancang untuk mendapatkan kesan-kesan tertentu di benak pembaca. Proses ini tentu saja tidak dilakukan secara asal-asalan oleh pembuat iklan atau konten, tetapi memerlukan keahlian baik dalam memilih model/endorser, pakaian, komposisi, teknik pencahayaan, hingga pose, sehingga foto yang dihasilkan siap dipakai sebagai proses pertandaan bagi pembaca. (3) Objek. Metode ini mirip dengan tahap Pose, namun dalam pandangan Barthes, tahap objek lebih pada bagaimana suatu proses produksi foto, terutama berkaitan dengan objek-objek seperti pakaian, orang, benda-benda hingga latar belakang akan memiliki daya tarik besar apabila bisa merujuk pada jejaring ide tertentu. Sebagai contoh, foto yang terdapat objek rak buku dapat merujuk pada intelektualitas, atau latar belakang rumah dan interiornya dapat merujuk pada gagasan mengenai kesan rumah bergaya tradisional atau modern. (4) Fotogenia. Teori fotogenia, menurut Barthes, dapat diartikan sebagai aspek-aspek teknis dalam produksi foto, seperti pencahayaan dan pencetakan hasil. Namun demikian, dalam budaya visual masa kini yang dekat dengan dunia digital, teknik produksi foto telah melampaui aspek-aspek tersebut. Teknik digital dapat merekayasa/manipulasi, memberikan efekefek, pemotongan (cropping) pada bagianbagian tertentu sehingga dapat dikombinasikan dengan latar belakang yang berbeda, hingga teknik-teknik lain. Prosesproses tersebut, seringkali digunakan untuk memberikan kesan yang lebih menarik pada sebuah gambar (aesthetic effects), seperti lebih cerah dan halus pada area muka. Selain itu, Barthes juga mengatakan bahwa teknikteknik ini dapat dikembangkan sejauh masing-masing memiliki petanda konotasi penghubung yang terus-menerus membuka ruang bagi penerjemahannya ke dalam leksikon kultural. Misalnya, wajah cerah, bersih, dan putih berasosiasi dengan wajah orang modern, kekinian, berkesan cantik atau ganteng. (5) Estetisisme. Sifat-sifat estetik pada foto dalam pandangan Barthes di sini mengacu pada kesan-kesan tertentu yang dapat muncul dari imej yang direpresentasikan. Namun demikian, kesan tersebut bukanlah kesan yang sesungguhnya. Misalnya, pengalaman memaknai keindahan foto tidak sama dengan pengalaman memaknai pemandangan alam secara langsung. Apa yang direpresentasikan pada foto, dalam hal ini, merupakan cara mengada, bukan objek dari suatu pesan terstruktur. Dalam keilmuan desain grafis, terutama layout, metode menciptakan keindahan wujud visual dapat menggunakan prinsip-prinsip tertentu seperti keseimbangan (balance), mengatur proporsi, hingga dominansi. (6) Sintaksis. Dalam ilmu kebahasaan, sintaktis atau sintaktik merupakan komponen yang berkaitan dengan lambang atau sign serta bentuk hubungannya (Lyons dalam Aminuddin, 2008: 37). Barthes menggunakan cara ini untuk menafsirkan rangkaian suatu foto sehingga dapat dihasilkan suatu penanda konotasi. Pada penelitian ini, cara ini dapat 
digunakan untuk menafsir keterkaitan antar elemen tanda visual maupun visual dengan verbal (supra-linguistik) karena suatu objek desain komunikasi visual selalu melibatkan kedua unsur tanda tersebut.

\section{Gender}

Kata gender dalam istilah bahasa Indonesia sebenarnya berasal dari bahasa Inggris, yaitu 'gender'. Jika dilihat dalam kamus bahasa Inggris, tidak secara jelas dibedakan pengertian antara sex dan gender. Seringkali gender dipersamakan dengan seks (jenis kelamin-laki-laki dan perempuan). (Nugroho, 2008: 1). Dalam buku yang sama, menurut Stoller (1968), istilah gender pertama kali diperkenalkan untuk memisahkan pencirian manusia yang didasarkan pada pendefinisian yang bersifat sosial budaya dengan pendefinisian yang berasal dari ciri-ciri fisik biologis.

Kenyataan biologis memang dapat digeneralisir, tetapi tidak sama untuk semua orang, pada waktu lahir terjadi perbedaan biologis secara nature, alamiah, kodrat Ilahi yang tidak dapat diberontaki. Namun bayi yang baru lahir, kemudian "dibentuk" oleh lingkungan hidupnya yang dinamakan sosialisasi. Pada sisi inilah, berbagai nilai bisa berbeda, juga bisa sama (Murniati, 2004: xviii)

Gender merupakan behavioral differences (perbedaan perilaku) antara lakilaki dan perempuan yang dikonstruksi secara sosial, yakni perbedaan yang bukan ketentuan Tuhan melainkan diciptakan oleh manusia (bukan kodrat) melalui proses sosial dan kultural yang panjang. Dasar sosialisasilah yang secara kuat membentuk suatu ideologi yang disebut ideologi gender. Ideologi ini membentuk konstruksi sosial yang melembaga. Perempuan dan laki-laki dibedakan atas dasar kepantasannya. Kemudian dibuatkan label yang ditempelkan kepada masing-masing jenis untuk membedakan. Perbedaan dengan jenis label ini, menciptakan pandangan stereotip bagi perempuan dan laki-laki. (Murniati, 2004: xviii)

Dalam arti kedaerahan, menurut Illich (2007: 3) gender membeda-bedakan tempat, waktu, alat-alat, tugas-tugas, bentuk-bentuk wicara, gerak-gerik, dan persepsi, yang dihubungkan dengan lelaki dan dihubungkan dengan perempuan dalam kebudayaan. Asosiasi itu membentuk gender sosial karena ia secara khusus terikat pada tempat dan waktu tertentu. Dalam hal ini, Illich menyebutnya gender kedaerahan karena rangkaian penghubungan itu khas sekelompok masyarakat tradisional di wilayah geografis tertentu, sama seperti logat bahasa.

Dalam perkembangannya, gender menciptakan berbagai fenomena di berbagai negara dan budaya, seperti konsep maskulinfeminin, patriarki-matriarki, superioritasinferioritas, hingga wacana-wacana yang menggambarkan adanya ketidaksetaraan, ketidakadilan atau ketimpangan gender. Di dalam masyarakat, ketidakadilan gender termanifestasi antara lain dalam bentuk marjinalisasi, subordinasi, kekerasan, stereotipe, dan beban kerja. (Nugroho, 2008: 17).

Dalam hal beban kerja, Nugroho juga menambahkan, beban kerja yang diakibatkan dari bias gender kerap kali diperkuat dan disebabkan oleh adanya keyakinan/pandangan di masyarakat bahwa pekerjaan yang dianggap masyarakat sebagai jenis pekerjaan perempuan, seperti semua pekerjaan domestik, seperti memasak, manajemen rumah tangga, mengurus anak, dianggap dan 
dinilai lebih rendah dibandingkan dengan jenis pekerjaan yang dianggap sebagai pekerjaan laki-laki, seperti bekerja sebagai manajer, direktur, kepala bagian, dan sebagainya, dan pekerjaan domestik tersebut dikategorikan sebagai pekerjaan yang bukan produktif sehingga tidak diperhitungkan dalam statistik ekonomi negara. Dalam pandangan Illich (2007: 4) apa pun corak ekonominya, perempuan selalu memperoleh lebih sedikit dari laki-laki.

Sementara itu kaum perempuan, berkaitan dengan anggapan gender, sejak dini telah disosialisasikan untuk menekuni peran gender mereka. Di lain pihak kaum laki-laki tidak diwajibkan secara kultural untuk menekuni berbagai jenis pekerjaan domestik itu. Kesemuanya ini telah memperkuat pelanggengan secara kultural dan struktural beban kerja kaum perempuan. Fenomena tersebut, menurut Bourdieu (2010: 85), membuat laki-laki tidak bisa merendahkan diri, tanpa merasa terhina, untuk melakukan tugas-tugas yang secara sosial dianggap hina (sebab laki-laki dianggap terlalu tinggi untuk melakukannya). Akan tetapi, tugas-tugas yang hina itu bisa juga menjadi terhormat dan dianggap sulit, jika dilakukan oleh laki-laki. Dalam pengertian, suatu 'pekerjaan perempuan', akan tampak lebih baik bila dikerjakan oleh laki-laki.

Bias yang mewujud dalam beban kerja tersebut selanjutnya menjadi semacam 'norma standar gender' yang di tahap selanjutnya dapat menciptakan suatu skala penyimpangan. Dalam pengertian, norma tersebut menciptakan pengkategorian atas kemaskulinannya atau kefemininannya berdasarkan kesepakatan mengenai norma yang berlaku. Masyarakat umumnya kurang menerima perilaku yang menyimpang dari norma standar, maka berkembanglah mitos bahwa terdapat dua gender yang sangat berbeda satu dengan lainnya. (Nugroho, 2008: 19)

Pada dasarnya, selama pandangan itu tidak mengarah kepada hubungan yang tidak adil, tidak menjadi soal. Namun ternyata, perbedaan gender ini menciptakan diskriminasi yang timpang, dengan pihak perempuan pada posisi yang dirugikan. Diskriminasi ini, apabila tidak dipersoalkan, akan semakin keras dan keji, akhirnya sampai pada tindakan yang tidak manusiawi (dehumanisme), baik bagi perempuan dan bahkan juga bagi laki-laki. (Muniarti, 2004: xix)

\section{Gender, Indonesia, dan Budaya Jawa}

Di Indonesia terutama semenjak dimulainya era Orde Baru, permasalahan gender terkait dengan beban kerja seringkali tidak selalu dipandang negatif layaknya budaya Barat, terutama terkait peran perempuan dalam pembangunan negara. Menurut Permanadeli (2015: 221) di era Orde Baru kemajuan pembangunan tidak selalu melihat laki-laki sebagai elemen utama, tetapi juga kaum perempuan sebagai penggeraknya. Perempuan dalam proses pembangunan diberikan kesempatan untuk bekerja. Selain itu, juga diberikan kesempatan untuk meningkatkan pengalamannya di ruang sosial, yang kemudian ditampung oleh organisasi resmi negara seperti Dharma Wanita dan PKK (Perkumpulan Kesejahteraan Keluarga). Skolarisasi atau kesempatan bagi perempuan untuk bersekolah juga menjadi agenda dalam era Orde Baru. Laki-laki dan perempuan, dalam hal ini memiliki kesempatan yang sama dalam pembangunan. Ini menjadi cukup berbeda dengan ideologi gender di Barat yang seringkali menciptakan diskriminasi karena 
peran sosial banyak dipengaruhi oleh stereotip gender, di mana laki-laki lebih banyak mendominasi di ranah publik, sedangkan perempuan cukup ditempatkan di ranah domestik.

Wujud pembangunan era Orde Baru yang melibatkan perempuan salah satunya adalah karena Soeharto sebagai presiden kala itu banyak menerapkan budaya Jawa. Sebagian besar birokrat Indonesia juga menerapkan budaya Jawa. Bahkan Soeharto sendiri pun selalu diilhami oleh budaya Jawa dan memakai seluruh perangkat budaya tersebut untuk menyampaikan pikiran dan perilakunya. (Permanadeli, 2015: 201-203) Pandangan tersebut dapat digunakan untuk melihat bahwa proses pembangunan di Indonesia selama kurun waktu 32 tahun, banyak dipengaruhi oleh budaya Jawa.

Perempuan dalam budaya Jawa, bisa melakukan apapun yang mereka ingin lakukan, seperti bekerja di luar rumah, asalkan tidak menelantarkan rumah tangganya. Modernitas secara mental dijabarkan oleh perempuan sebagai alat yang bisa mereka gunakan untuk memperkuat gagasan, bahwa rumah tangga adalah tempat penyempurnaan diri mereka sebagai perempuan Jawa. Gagasan tersebut direpresentasikan oleh pekerjaan dan penampilan. (Permanadeli, 2015: 198-199)

Namun demikian, saat ini persoalan mengikuti tren berpakaian modis untuk menunjukkan kesan gaya hidup modern bagi perempuan tidak selalu terkait dengan bekerja, tetapi dapat diikuti dan bahkan dibeli melalui internet. Dalam hal ini, bagi perempuan masa kini, menjadi modis dan modern tetap dapat dilakukan meskipun posisinya adalah sebagai ibu rumah tangga.

Dari penelitian yang dilakukan oleh Permanadeli juga ditemukan hasil bahwa untuk perempuan Jawa sendiri, aspek sosial bekerja ternyata lebih penting daripada aspek produktifnya. Kaum perempuan dapat meningkatkan kualitas karakter personal, berorganisasi, membantu orang lain, hingga mengikuti tren gaya hidup di luar rumah. Bekerja, dalam arti tertentu adalah sebuah ruang lain dalam hidup sosial perempuan yang berfungsi untuk memperkaya kehidupan rumah tangga. Namun demikian, fenomena tersebut memang tidak dapat digunakan untuk generalisasi. Perempuan yang bekerja dapat dikarenakan berbagai faktor, mulai dari kemiskinan hingga perceraian.

\section{Dadi Wong Sebagai Wujud 'Kesejatian}

\section{Laki-laki'}

Tema kampanye Akademi Suami Sejati produk kecap ABC melalui media sosial Instagram menggunakan kata: Sejati. Kata ini menjadi jargon yang dikumandangkan produk sebagai nilai jual untuk menciptakan gagasan mengenai kualitas laki-laki sebagai sosok yang perlu berperan dalam aktivitas domestik. Untuk melihat pemaknaan mengenai sejati, konsep mitos mengenai laki-laki sejati akan memakai konsep Dadi Wong dalam budaya Jawa. Dadi Wong dalam penelitian ini digunakan bukan untuk melihat dari satu paradigma geografis atau kesukuan untuk menilai dan mendefinisikan akan makna sejati, tetapi berangkat dari asumsi bahwa ideologi gender di Indonesia saat ini, merupakan hasil dari hegemoni budaya Jawa yang dibentuk pada masa Orde Baru oleh Soeharto.

Menurut Permanadeli (2010: 252) istilah kekuasaan digunakan untuk berbicara tentang laki-laki sedangkan tentang perempuan ungkapan yang digunakan pun dikaitkan dengan rumah tangga secara fisik 
dan afektif. Umumnya, penggunaan terminologi kekuasaan untuk menegaskan tempat laki-laki dalam masyarakat Jawa muncul dari sebuah gagasan khusus. Gagasan kekuasaan itu terikat dengan kemampuan untuk memberi perlindungan dan kemampuan untuk merengkuh semua daya hidup baik yang merujuk pada kualitas kedewasaan sekaligus kualitas sebagai manusia. Oleh karena itu, gagasan kekuasaan tidak mencerminkan watak kesewenangan, tidak memendam prinsip hierarki yang kemudian membuat lahirnya dorongan untuk menggugat kesetaraan oleh perempuan karena memang bukan prinsip hak yang membuat kehadiran setiap orang (laki-laki dan perempuan) pada ruang rumah tangga tadi.

Tabel 2 Tabel 1. Kriteria Dadi Wong versi penelitian Risa Permanadeli

\begin{tabular}{|l|c|c|}
\hline & $\begin{array}{c}\text { N narasumber } \\
(\mathrm{T}=94)\end{array}$ & $\%$ \\
\hline Penghasilannya baik & 91 & 96,8 \\
\hline Punya pekerjaan tetap & 88 & 93,6 \\
\hline Keluarganya harmonis & 78 & 83 \\
\hline Bisa menyekolahkan anak & 59 & 62,8 \\
\hline Sekolahan & 48 & 51 \\
\hline Bisa bantu orang lain & 43 & 45,7 \\
\hline
\end{tabular}

Sumber: Risa Permanadeli, 2010: 125

Seperti ungkapan dari Dewi Soekarno dalam Permanadeli (2010: 259), bahwa perempuan menjadi perempuan karena dia hidup sesuai dengan kesadaran sosialnya sebagai perempuan, dan laki-laki menjadi laki-laki karena hidup menurut kesadaran sosialnya sebagai laki-laki. Ada prinsip yang menegaskan bahwa tiap orang harus bertindak sesuai dengan kesadaran sosialnya.

\section{New Media}

New media secara sederhana dapat didefinisikan sebagai perkembangan mediamedia tradisional seperti televisi, koran, radio dsb. ke bentuk yang baru yaitu digital, dengan diperantarai oleh internet. Pada media tradisional, suatu bentuk komunikasi secara umum menciptakan suatu pesan yang bersifat vertikal, di mana informasi yang didistribusikan oleh media seperti televisi, hanya dapat diterima oleh audiens tanpa dapat menciptakan interaksi atau timbal balik. Audiens, dalam hal ini, cenderung bersifat pasif (one-to-many). New media menciptakan kondisi di mana audiens dapat bersifat aktif karena new media dapat menciptakan interaksi antara audiens dengan pembuat pesan. Seperti halnya dalam dunia media sosial, di mana audiens dapat memberikan respon berupa komentar, menyukai (like), hingga menyebarkan informasi tersebut secara luas (many-to-many).

New media, menurut Lister dkk. (2009), selalu berkaitan dengan: digital, interaktif, hyperteks, virtual, jaringan dan simulasi.

\section{Pemasaran Konten (Content Marketing)}

Singkat kata menurut Kotler dkk. (2019: 119), pemasaran konten adalah pendekatan pemasaran yang mencakup menciptakan, memilih, membagi, dan memperbesar konten yang menarik, relevan, dan berguna untuk kelompok khalayak yang jelas demi menciptakan percakapan tentang kontennya. Pemasaran konten juga dianggap sebagai bentuk lain dari jurnalisme merek dan penerbitan merek yang menciptakan hubungan yang lebih dalam antara merek dan pelanggan. Merek yang melaksanakan pemasaran konten yang baik menyediakan 
akses untuk pelanggan pada konten asli berkualitas tinggi sambil menceritakan kisah menarik tentang merek mereka dalam prosesnya. Pemasaran konten menggeser peran pemasar, dari promotor merek menjadi pencerita.

\section{ANALISIS}

Proses analisis data dalam penelitian ini meliputi dua tahapan. Pertama, adalah identifikasi struktur mitos yang terdapat pada konten. Tahap ini menggunakan metode pembedahan struktur tanda dari Roland Barthes dengan cara membongkar tanda denotatif dan konotatif. Tanda denotatif menginterpretasi makna apa adanya dari objek yang diteliti, sedangkan tanda konotatif menginterpretasi makna kedua dan dibagi menjadi tiga yaitu konotatif perseptif, kognitif dan etis. Setelah itu dilakukan analisis mitos dari dua objek desain yang diteliti.

\section{Analisis Desain 1. Unggahan Gambar}

\section{Penanda:}

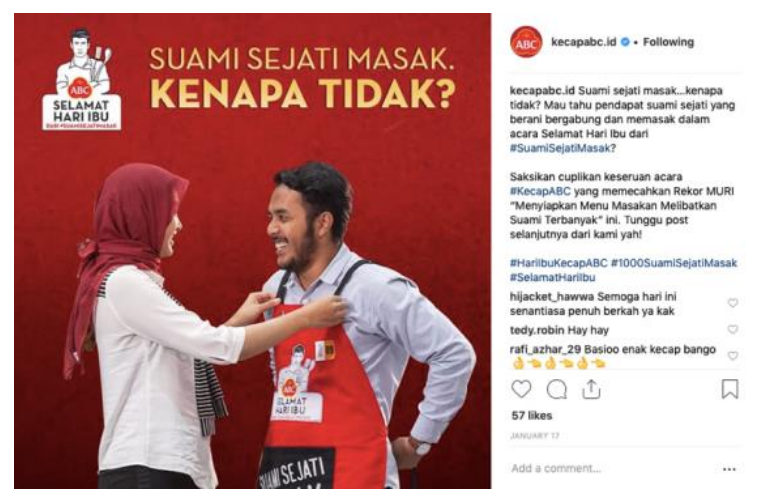

Gambar 1 Unggahan Konten terkait acara Selamat Hari Ibu yang diselenggarakan Kecap ABC

Analisis Petanda: Unggahan di atas memiliki bentuk kotak (square) dengan latar belakang dominan merah tua. Unggahan tampak didominasi foto laki-laki dan perempuan yang tampak berhadapan di mana sosok perempuan sedang memegang celemek yang dipakai lakilaki. Pada bagian kiri atas terdapat logo dari tema dengan tulisan SELAMAT HARI IBU DARI \#SUAMISEJATIMASAK, dan bagian kanan atas terdapat kalimat pernyataan: SUAMI SEJATI MASAK. Disusul dengan kalimat tanya: KENAPA TIDAK? Unggahan ini merupakan salah satu bagian dari tema Akademi Suami Sejati yang memanfaatkan momen kultural.

Tanda denotatif: Sosok perempuan dan lakilaki pada gambar dapat diartikan sebagai pasangan suami istri. Makna tersebut dapat terlihat dari konteks teks unggahan yang terdapat unsur kata SUAMI, sehingga pasangan tersebut tidak dimungkinkan diartikan sebagai ibu-anak, atau pasangan yang belum menikah. Ditinjau dari konteks tema unggahan dan caption, gambar tersebut dapat diartikan sosok istri yang sedang mempersiapkan celemek untuk sang suami yang akan melakukan aktivitas memasak di acara Selamat Hari Ibu yang diselenggarakan oleh produk Kecap ABC.

Penanda Konotatif: analisis mengenai penanda konotatif menggunakan pendekatan Barthes yaitu konotatif perseptif, kognitif dan etis.

Konotatif Perseptif: Komposisi dan rekayasa digital yang digunakan pada unggahan ini menunjukkan bahwa foto suami-istri diposisikan sebagai elemen visual yang dominan dalam ruang gambar. Ketiadaan latar belakang dan penggunaan warna merah hati dengan proses cropping menciptakan kontras pada gambar sehingga foto lebih mudah terlihat. Hal tersebut akan berbeda apabila foto menggunakan latar belakang bernuansa lingkungan yang akan 
mengurangi tingkat atensi saat melihat. Ditinjau dari metode fotogenia Barthes, penggunaan teknik ini secara jelas mengarahkan pembaca agar secara langsung berinteraksi dengan imej foto dan di tahap selanjutnya, memahami pesannya dengan mengaitkannya pada teks.

Sosok suami istri yang ditampilkan pada unggahan ini tampak mengenakan pakaian dengan kesan modern, modis, dan formal. Pakaian dapat diartikan: (1) menunjukkan suatu kelas sosial tertentu. (2) menciptakan sistem penandaan pada audiens mengenai hubungan antara pakaian dengan acara memasak, dan (3) suami tetap memperhatikan penampilan walaupun hendak memasak.

Arti ketiga dapat digunakan untuk melihat hubungan antara laki-laki, pakaian dan memasak. Pakaian rapi, formal, dan penggunaan aksesoris seperti jam tangan untuk aktivitas memasak cenderung kurang fungsional karena proses memasak menggunakan bahan-bahan, alat hingga api untuk memasak yang dapat mengotori dan membuat tubuh berkeringat. Pakaian kemeja, dalam hal ini, tampak terlalu berlebihan. Pakaian jenis ini akan lebih sesuai untuk bekerja. Pemilihan foto yang merepresentasikan laki-laki pada unggahan ini dapat diartikan untuk menunjukkan bahwa aktivitas di ruang domestik, yaitu memasak, juga perlu untuk memperhatikan penampilan. Memasak disetarakan dengan pekerjaan utama. Namun demikian, tujuan dari peluh keringat yang dihasilkan berbeda. Suami bekerja untuk kebutuhan ekonomi, sedangkan memasak untuk keharmonisan rumah tangga dalam wujud kesetaraan beban kerja.

Penggunaan kata: LELAKI SEJATI MASAK. KENAPA TIDAK? dapat diartikan sebagai kalimat yang 'menantang' bagi lakilaki. Kata 'tidak' dapat diteruskan kelanjutannya seperti: "apakah salah apabila laki-laki memasak?”, “haruskah laki-laki merasa malu untuk membantu istri di dapur?" dan sebagainya yang orientasinya adalah, beranikah laki-laki melakukannya? Foto pada unggahan ini menunjukkan bahwa suami menerima 'tantangan' dari kecap ABC untuk menjadi suami sejati. Sosok suami yang tersenyum ceria sambil memandang istri dan siap untuk memasak menggambarkan bahwa laki-laki tidak 'terpaksa' untuk melakukan, tetapi dengan senang hati. Bahkan, sosok istri pun tampak membantu merapikan celemek yang digunakan sebelum suami memasak.

Konotatif Kognitif: Melalui analisis konotasi perseptif di atas, diperoleh tiga makna mengenai pakaian dan aksesoris pada tubuh, yaitu: (1) menunjukkan suatu kelas sosial tertentu. (2) menciptakan sistem penandaan pada audiens mengenai hubungan antara pakaian dengan acara memasak, dan (3) suami tetap memperhatikan penampilan walaupun hendak memasak. Pertama, pakaian yang dikenakan merepresentasikan kelas sosial menengah hingga menengah ke atas. Hal tersebut terlihat dari jenis pakaian yang secara umum digunakan oleh karyawan yang bekerja di tempat formal, modern, stabil secara keuangan karena bergaji di atas ratarata, dan umumnya hidup di perkotaan. Pakaian tidak menggambarkan jenis pekerjaan yang identik dengan 'kerja fisik' seperti buruh, petani, atau pakaian yang beridentitas atau berseragam seperti TNI atau PNS. Selain itu, pakaian cenderung kurang menggambarkan tipe pekerja kreatif atau freelancer yang seringkali lebih bebas dalam berpakaian saat bekerja, yang bahkan sering menggunakan kaos oblong atau baju yang kurang formal seperti polo shirt yang menunjukkan kedinamisan bekerja. 
Aktivitas suami modern yang bekerja di perkotaan cenderung identik dengan kesibukan, kemacetan, yang bekerja dari pagi hari dan pulang seringkali hingga larut malam karena terjebak macet. Waktu untuk bersama keluarga (family time) maupun aktivitas di ruang domestik, akhirnya menjadi minim. Kecapekan suami dalam bekerja seringkali terobati di akhir pekan atau hari libur melalui berbagai aktivitas, mulai dari pekerjaan rumah maupun liburan keluarga. Aktivitas rekreatif menjadi agenda penting bagi keluarga modern yang hidup di perkotaan sebagai upaya refreshing maupun untuk menghindari berbagai permasalahan keluarga.

Kedua, dari pemaknaan mengenai jenis pakaian dan pekerjaan, ketika diasosiasikan dengan acara memasak untuk memperingati hari Ibu yang dibuat oleh Kecap $\mathrm{ABC}$, dapat diartikan bahwa tipe laki-laki modern dari kelas menengah dan menengah atas diposisikan sebagai target audiens, baik untuk acara maupun produk. Kecap ABC melalui kampanye ini juga tampak berupaya mempersuasi suami modern untuk ikut berpartisipasi dalam pembelian produkproduk rumah tangga atau belanja bulanan, terutama produk untuk kegiatan memasak sebagai wujud kesetaraan gender.

Ketiga, penampilan suami tampak sangat diperhatikan oleh Kecap ABC, terutama pakaian. Hampir tiap konten yang diunggah, baik dalam wujud gambar maupun video, sosok suami selalu ditampilkan rapi dan 'menawan'. Kecap ABC tampak menjaga kesan bahwa aktivitas memasak tidak selalu identik dengan kegiatan yang menyulitkan dan kotor karena terkena bahan-bahan tertentu, sehingga suami pun tidak perlu mengganti pakaian yang lebih cocok untuk kegiatan memasak. Dandanan yang rapi dan bersih, juga dapat berasosiasi dengan pakaian chef atau koki profesional, meskipun yang ditampilkan pada konten tidak selalu berwarna putih. Secara umum diketahui bahwa pakaian seorang chef atau koki, yang sering disebut chef jacket, tidak hanya memiliki nilai fungsional tetapi juga estetis. Di satu sisi, pakaian chef digunakan untuk melindungi tubuh, dan di sisi lain, saat akan bertemu dengan tamu tidak mungkin dengan chef jacket yang kotor. Oleh karena itu koki dapat membalikkan bagian yang kotor dengan bagian yang bersih menggunakan kancing lainnya. (https://travel.kompas.com. Diakses Oktober 2019).

Konotatif Etis. Secara umum diketahui bahwa aktivitas memasak selalu identik dengan perempuan atau istri, dan suami lebih banyak melakukan aktivitas publik. Melalui kampanye ini, Kecap ABC tampak berupaya untuk mengubah 'norma' tersebut dan memosisikan kegiatan memasak juga dapat dilakukan oleh kaum laki-laki. Pakaian, dalam hal ini, digunakan untuk memperkuat kesan bahwa memasak merupakan aktivitas yang menarik, fun, tanpa 'merendahkan' citra maskulin.

Selain itu, dandanan khas suami modern yang diramu dengan memasak dapat diartikan sebagai bentuk 'kesetaraan' antara kegiatan formal seperti bekerja, dengan kegiatan domestik. Memasak bukanlah hal yang sepele, murahan, dan hina, tetapi perlu dilakukan dengan kesungguhan tenaga dan pikiran selayak bekerja. Kesetaraan juga dapat diartikan bahwa pekerjaan seorang suami, selalu terkait dengan kesejahteraan rumah tangga, yaitu ekonomi.

Aktivitas memasak, dalam hal ini pun juga diposisikan sebagai wujud kesungguhan atau kepedulian seorang suami untuk ikut berpartisipasi secara sungguh-sungguh dan 
penuh semangat di ruang domestik demi keharmonisan rumah tangga, tidak seperti halnya sedang memasak air, mi instan atau menggoreng telur di dapur yang identik dengan pakaian non formal atau seadanya, seperti kaos oblong, yang mudah dan terlampau banal. Kecap ABC, melalui tema ini, berupaya menciptakan suatu sistem pertandaan yang menggabungkan antara gagasan fashion dan memasak, untuk mendorong dihasilkannya mitos aktivitas yang layak, terhormat, dan bergengsi bagi kaum laki-laki.

\section{Analisis Desain 2. Film iklan}

Analisis pada film iklan ini akan dibuat menjadi tabel yang berisi lima scene utama dari adegan untuk mempermudah dalam proses pemaknaan. Masing-masing scene akan diberikan keterangan mengenai gambaran besar alur cerita berikut dialognya.

Tabel 3 Scene film iklan produk Kecap ABC






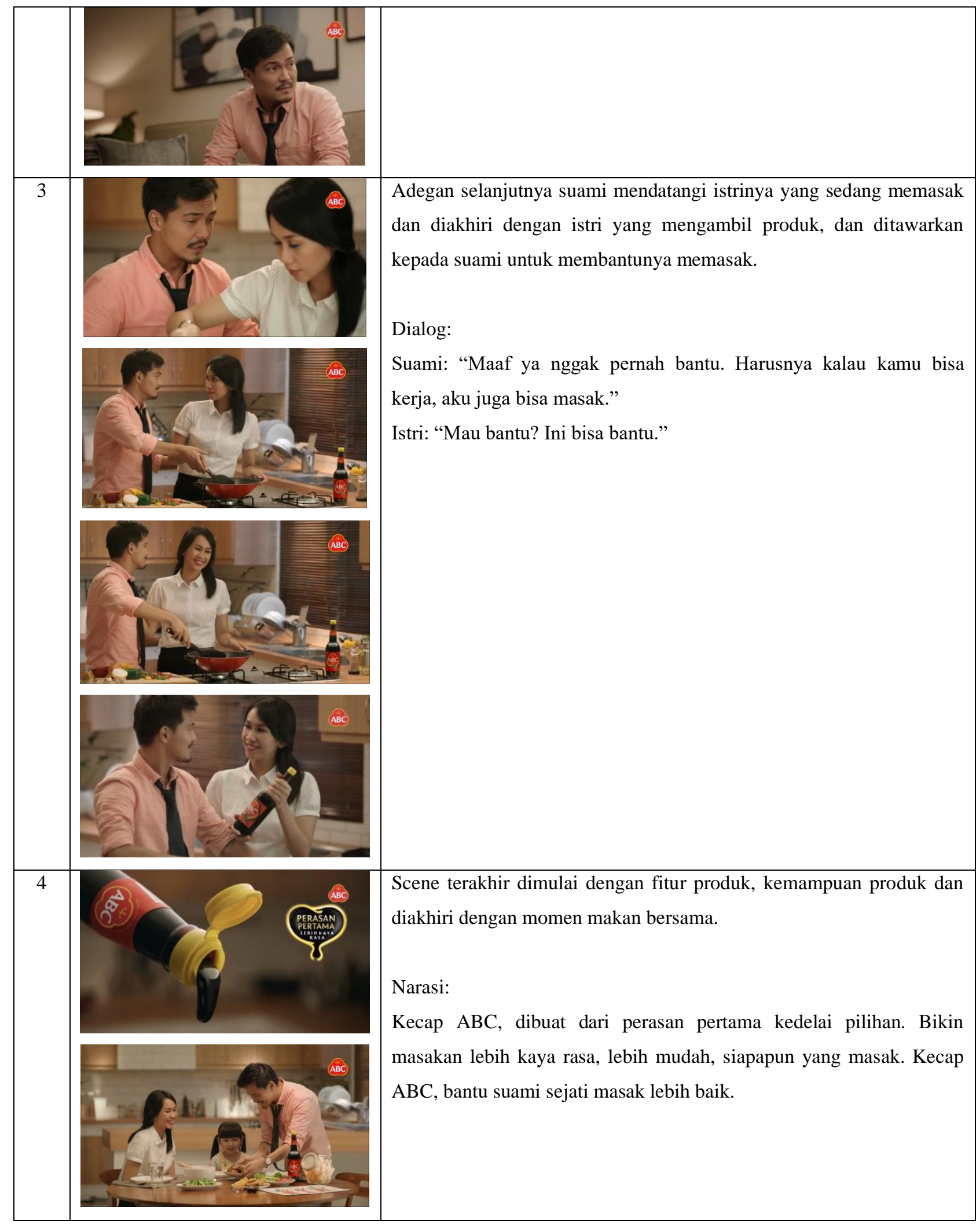




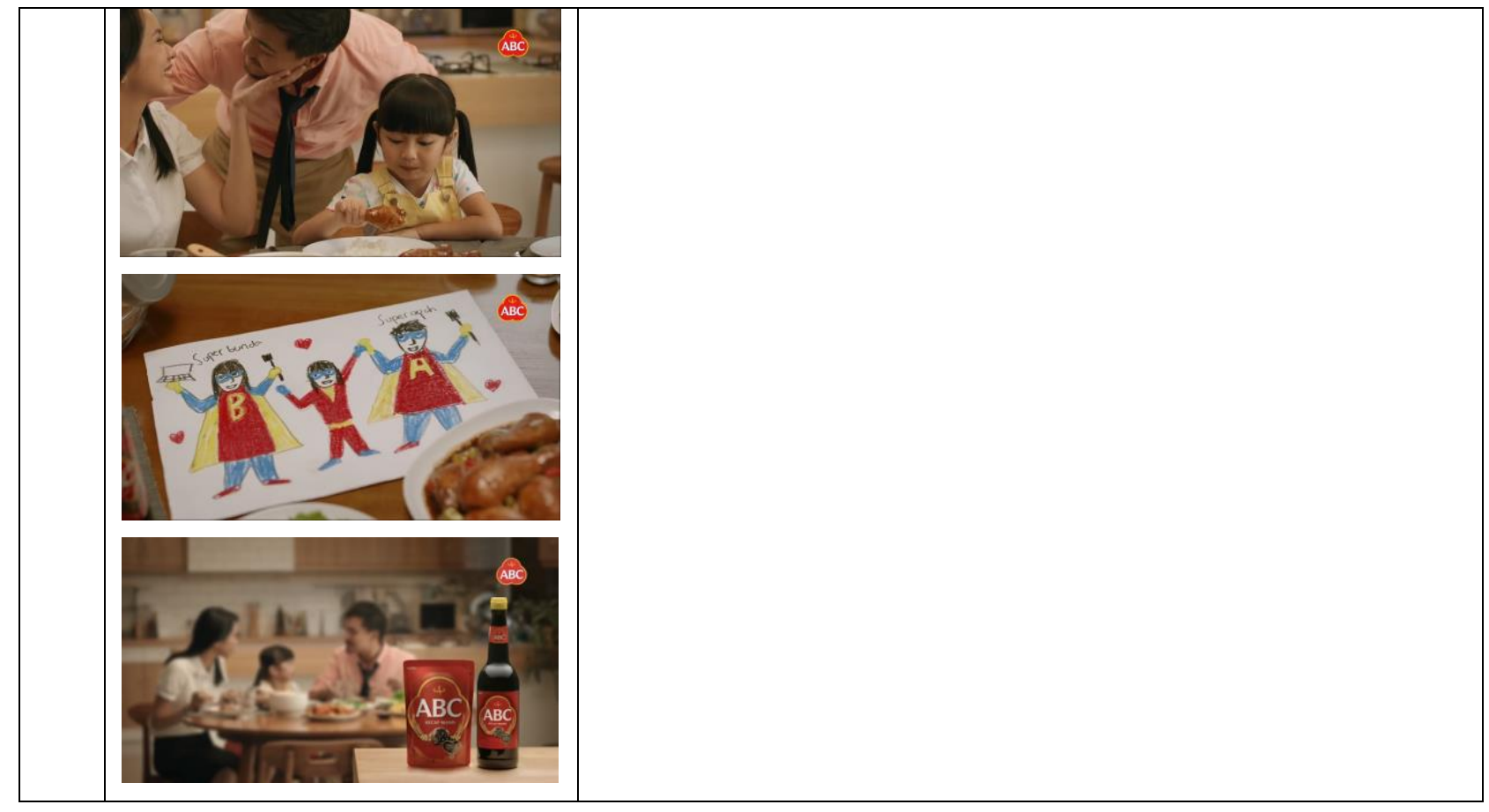

Analisis Petanda: Film iklan yang menggunakan format persegi (widescreen) ini setidaknya memiliki lima scene utama, dengan penjelasan sebagai berikut: (1) momen saat kepulangan ayah/suami dan ibu/istri ke rumah, (2) momen saat ayah sedang berbicara dengan anak perempuannya, (3) momen ketika suami-istri berinteraksi di dapur, (4) fitur produk, dan (5) scene saat ayah, ibu dan anak sedang bercengkrama di meja makan yang diakhiri dengan tampilan produk.

Tanda denotatif: Secara keseluruhan, unggahan dalam bentuk film di atas menggunakan setting di dalam rumah, dengan ruang keluarga dan dapur sebagai lingkungan utamanya. Scene pertama dapat diartikan sebagai momen kepulangan ayah dan ibu ke rumah sepulang dari bekerja, hal tersebut tampak dari pakaian yang digunakan. Ayah memakai baju formal berupa kemeja yang digulung pada bagian lengannya dan tampak rapi karena bagian bawah kemeja dimasukkan di celana, sedangkan ibu memakai pakaian formal berwarna putih dengan bawahan hitam. Pakaian yang digunakan cukup identik dengan baju kerja. Momen pulang kerumah tersebut diawali dengan rasa lelah yang dialami oleh ayah sehingga ketika masuk rumah langsung duduk di kursi sembari mengucap: "Ahh, capek." Di saat yang lain, ibu tampak sedang mempersiapkan diri di dapur untuk langsung memasak begitu pulang.

Scene kedua merupakan dialog ayah dan anak, di mana ayah menanyakan perihal gambar buatan anaknya. Adegan dapat diartikan sebagai rasa penasaran ayah pada gambar berwujud hero buatan anaknya, hal tersebut tampak dari pertanyaan dugaan yang langsung diajukan begitu duduk. Dialog yang terjadi pada scene ini adalah sebagai berikut:

Ayah: "Itu adek ya?"

Anak: "Ini super bunda." Ayah: "Kekuatan super bunda apa?" Anak: "Banyak, bangun pagi, kerja, masak." 
Ayah: "Kalau ayah?"

Anak: "Ayah cuman ngantor, bunda udah ngantor masih kuat masak."

Jawaban dari anak dapat diartikan sebagai bentuk korektif karena pertanyaan ayah yang berupa dugaan, ternyata salah. Setelah memberikan jawaban, ayah memberikan pertanyaan lanjutan yang bersifat komparatif, yaitu pertanyaan mengenai perbandingan kekuatan antara ayah dan ibunya. Jawaban anak dapat diartikan bahwa ibu memiliki kekuatan yang lebih banyak dari ayahnya. Di akhir scene ini, tampak ekspresi ayah menjadi berbeda dari sebelumnya setelah mendengar jawaban anaknya, dan tampak berpaling ke arah dapur dan kemudian ke arah anaknya. Momen ini diakhiri dengan wujud kegelisahan ayah karena mendengar jawaban anaknya.

Scene ketiga menggambarkan interaksi antara ayah dan ibu, di mana ayah meminta maaf karena tidak pernah membantu istri di dapur. Scene diakhiri dengan istri yang memberikan produk kecap ABC untuk membantu suami memasak. Dapat diartikan, scene ini secara jelas menggambarkan respon atas kegelisahan ayah setelah mendengar jawaban anak.

Scene keempat menggambarkan fitur atau kemampuan produk sebagai bahan penting agar masakan menjadi lebih kaya rasa. Selanjutnya terdapat adegan anak yang sedang makan masakan ayahnya dan diakhiri dengan makan bersama. Scene ini dapat diartikan sebagai outcome dari permasalahan yang terjadi, yaitu produk kecap $\mathrm{ABC}$ yang berperan menyelesaikan masalah memasak.

Penanda Konotatif: Analisis mengenai penanda konotatif menggunakan pendekatan Barthes yaitu konotatif perseptif, kognitif dan etis.
Konotatif Perseptif Scene 1: Dari sisi sinematografi, film ini secara keseluruhan menggunakan tone warna hangat (warm). Nuansa ini dapat diartikan untuk menunjukkan suasana kepulangan ayah dan ibu yaitu di waktu sore/menjelang malam atau malam hari. Hal tersebut diperkuat dengan lampu ruangan yang menyala. Suasana menggambarkan pula bahwa ayah dan ibu tersebut adalah tipe pekerja yang rela pulang hingga sore atau malam hari demi kesejahteraan keluarga. Pulang larut juga dapat memiliki beberapa arti: (1) karena faktor jalanan yang macet, (2) lembur, (3) tempat kerja yang jauh dari rumah, atau (4) memiliki pengasuh anak karena ayah dan ibu seharian di luar rumah untuk bekerja.

Kondisi pulang hingga sore larut atau malam hari banyak dijumpai di daerah perkotaan, dan sangat jarang dijumpai di daerah perdesaan atau kota-kota kecil karena tempat bekerja secara umum dekat dengan rumah, misalnya sawah, kebun, memiliki warung di rumah atau berjualan di pasar tradisional.

Selain tonalitas warna, interior rumah utama pada film iklan ini dapat diartikan sebagai gambaran rumah kelas menengah, yang tampak dari pilihan furnitur, alat-alat seperti adanya kompor tanam, microwave, lukisan, hingga penataan barang yang berkesan minimalis. Barang-barang tersebut memiliki harga yang cukup mahal, dan cenderung kurang terjangkau dan tidak dibutuhkan untuk kelas menengah ke bawah.

Kondisi capek yang dialami oleh ayah pada scene ini juga dapat diartikan sebagai penguat dari kondisi kelas pekerja yang hidup di perkotaan. Sosok ayah yang tampak lelah menunjukkan bahwa pekerjaan seorang lakilaki yang telah berkeluarga, yang dalam 
asumsi ini hidup di kota besar, memiliki beban kerja yang besar, baik dalam arti tenaga maupun pikiran. Penggambaran beban besar tersebut juga terwujud dengan sikap ayah yang langsung duduk dan mengeluh begitu sampai di rumah, tidak mencopot dasi atau menyapa anak istri terlebih dahulu yang, saat itu sedang di ruangan yang sama.

Selain dari sisi kepulangan, sosok ayah dan ibu yang bekerja dapat diartikan bahwa suami memberikan ijin kepada istri untuk bekerja di luar. Ini menunjukkan adanya budaya kesetaraan, yaitu bahwa perempuan tidak selalu diposisikan hanya sebagai ibu rumah tangga yang menghabiskan waktunya untuk pekerjaan domestik, tetapi dapat beraktualisasi diri di ruang sosial. Selain itu, suami istri yang bekerja menunjukkan suatu tuntutan kehidupan yang tinggi di daerah perkotaan.

Gaya pakaian suami istri yang cenderung formal dan tampak rapi dapat diartikan bahwa mereka bekerja di tempat yang profesional, dalam pengertian, suatu tempat kerja yang membutuhkan karyawan atau pekerja dengan penampilan yang sopan dan menarik. Suami juga tampak mengenakan dasi sebagai pelengkap kemeja yang memperkuat kesan bahwa suami bekerja untuk di tempat yang secara umum untuk kelas menengah. Makna konotatif ini dapat diciptakan karena kesan pakaian dapat dibandingkan dengan jenis pekerjaan untuk kelas menengah ke bawah, yang cenderung memakai pakaian yang non-formal, berseragam, dan jenis pakaian yang tidak terlalu mementingkan gaya busana untuk bekerja.

Konotatif Perseptif Scene 2: Rasa penasaran ayah terhadap gambar hero buatan anaknya yang diganjar dengan jawaban komparatif dapat diartikan bahwa anak adalah sosok pengamat kondisi keluarga, yang akhirnya dapat menyimpulkan bahwa ibu memiliki pekerjaan yang lebih banyak setiap harinya, sehingga di scene ini, anak lebih memilih ibu sebagai sosok pahlawan yang layak untuk digambar menjadi sosok superhero modern karena memiliki kekuatan yang lebih daripada ayah.

'Kekuatan' yang dimaksud anak pada scene ini dapat diartikan sebagai kekuatan dalam konteks ekonomi, yaitu bekerja untuk mendapatkan uang, sekaligus kekuatan dalam pekerjaan rumah, salah satunya adalah memasak. Bagi sosok anak, memasak merupakan suatu aktivitas yang membutuhkan kekuatan tersendiri, yaitu tenaga untuk mengolah bahan, menggunakan alat, proses memasak, hingga menyajikan. Kondisi lelah sepulang bekerja namun tetap mampu memasak tentu saja dianggap oleh anak sebagai kekuatan yang lebih daripada sekadar bekerja. Hal tersebut terlihat dari kata yang digunakan oleh anak untuk memperbandingkan ayah dengan ibunya, yaitu kata "cuman", yang seringkali identik dengan makna "belum ada ada-apanya."

Kegelisahan yang muncul dari ekspresi muka ayah mengenai jawaban anak dapat diartikan bahwa ayah merasa sosoknya sebagai suami belum ada apa-apanya apabila dibandingkan dengan istrinya yang dapat melakukan berbagai aktivitas, meskipun dalam kondisi lelah setelah bekerja.

Konotatif Perseptif Scene 3: Interaksi yang terjadi antara suami-istri di ruang dapur dapat diartikan sebagai respon ayah setelah mendengarkan jawaban anaknya. Dalam scene ini, suami tampak meminta maaf karena tidak pernah membantu istrinya di dapur, mencoba untuk membangun kesetaraan dalam 
rumah tangga. Hal tersebut tampak dari katakata suami: "Maaf ya nggak pernah bantu. Harusnya kalau kamu bisa kerja, aku juga bisa masak." Maksud kesetaraan suami di sini dapat diartikan bahwa suami perlu memiliki kesetimbangan dalam aktivitas rumah tangga. Dari sudut pandang kuantitas, beban kerja di sini adalah: 1 (suami) berbanding 2 (istri). Suami akhirnya merasa perlu untuk mengisi perbedaan jumlah aktivitas tersebut tanpa memandang bahwa pekerjaan barunya tersebut, secara umum jauh dari gengsi maskulin.

Adegan berlanjut dengan kesan istri yang merasa senang atas bantuan suami, yang tampak dari ekspresi wajah yang senang dan gestur tubuh. Scene diakhiri dengan momen pemberian produk kecap $\mathrm{ABC}$ dari istri untuk membantu suami saat memasak. Momen ini dapat diartikan: (1) istri 'membiarkan' suami untuk memasak sendiri dan produk diposisikan sebagai bahan yang dapat digunakan untuk membantu suami. Dalam hal ini, istri tidak perlu untuk mengajari suami cara memasak atau menemani untuk memasak bersama. Suami dapat mengerjakannya sendiri dengan bantuan produk. (2) penggunaan kata "ini bisa bantu" sembari menunjukkan produk dapat memiliki dualitas makna. Pertama, produk diposisikan sebagai bahan yang dipercaya oleh istri dalam memasak, dan ketika suami hendak membantu, produk kepercayaan istri tersebut dapat membantunya pula untuk memasak. Kedua, kata tersebut dapat berkesan satir untuk menunjukkan bahwa kecap ABC juga bisa membantu istri meskipun suami tidak memberikan bantuan untuk memasak.

Pada iklan ini, suami ditampilkan langsung menuju dapur untuk membantu istri untuk memasak tanpa mengganti baju terlebih dahulu yang 'lebih sesuai', misalnya kaos oblong agar lebih fleksibel. Ditinjau dari sisi pakaian, dalam hal ini dapat diartikan: (1) pakaian merepresentasikan suatu gagasan bahwa memasak diposisikan oleh suami sebagai aktivitas yang sama dengan pekerjaan utamanya. Memasak adalah aktivitas 'penting', memerlukan keahlian tertentu, dan perlu dilakukan dengan kesungguhan seperti halnya bekerja. Perbedaannya, bekerja dilakukan untuk menyelesaikan masalah keuangan, sedangkan memasak untuk menyelesaikan masalah ketidaksetaraan dan ketidakharmonisan dalam rumah tangga. (2) membantu istri untuk melakukan pekerjaan rumah tangga seperti memasak, bagi seorang laki-laki tidak perlu memandang kondisi seperti masih dalam kondisi lelah selepas bekerja atau mengganti baju yang lebih nyaman untuk memasak. Suami siaga, pada kampanye produk ini, memungkinkan sebagai gagasan pesan mengenai citra laki-laki.

Konotatif Perseptif Scene 4: Scene yang mengakhiri film iklan ini dimulai dari tampilan lelehan kecap dari botol yang mengenai masakan. Adegan selanjutnya adalah suami membawa hasil masakannya ke meja makan dan anak memakan daging ayam buatan ayahnya. Sosok superhero tampil menjadi tiga orang, yaitu ibu, ayah, dan anak, tidak lagi hanya satu seperti di awal. Scene dapat menunjukkan arti bahwa produk kecap ABC dapat menunjukkan kemampuannya untuk membantu suami memasak, yaitu dengan gambaran fitur produk yang mengenai masakan dari awal hingga menjadi kecoklatan karena terkena bahan kecap.

Produk kecap ABC, melalui iklan ini, selain merepresentasikan kemampuan produk, juga dapat diartikan bahwa produk juga memiliki kekuatan lain, yaitu menciptakan keharmonisan rumah tangga. 
Konotasi Kognitif. Konten menggambarkan bahwa permasalahan mengenai beban kerja dalam rumah tangga cenderung terjadi di kelas menengah ke atas. Namun demikian, permasalahan tersebut tidak menimbulkan suatu konflik yang mengarah pada kondisi negatif, seperti kekerasan dalam rumah tangga. Konflik internal lebih pada gambaran bahwa istri lebih banyak melakukan pekerjaan dibanding suami, yang ditunjukkan oleh sindiran anak kepada ayahnya. Kondisi tersebut dapat diartikan pula bahwa laki-laki dari kelas menengah ke atas dapat menyelesaikan suatu permasalahan dengan cara yang lebih humanis dan menyenangkan. Suami mengakui kekurangan dirinya, dan mengakui kelebihan dari pekerjaan istri sehingga rela membantu pekerjaan rumah tangga untuk mengurangi beban kerja istri. Namun demikian, sikap istri yang langsung merespon bantuan suami dengan cara memberikan botol kecap dapat memiliki dua pemaknaan yaitu: Pertama, istri berupaya 'melepaskan' diri dari proses memasak atau membantu suami karena tidak adanya adegan yang menggambarkan keduanya memasak bersama. Dalam hal ini, konten dapat menggambarkan pula suatu kondisi mengenai kelas sosial menengah ke atas yang cenderung individualis. Kedua, istri memberikan kesempatan kepada suami sepenuhnya untuk mengeksplorasi, merasakan, dan menikmati proses memasak, sehingga suami dapat mengetahui bagaimana kerepotan dan kesulitan dalam memasak.

Apabila dikaitkan dengan budaya Jawa, maka dapat dikatakan bahwa mitos maskulinitas yang dihadirkan oleh Kecap ABC melalui kampanye di media sosial dengan tema "Akademi Suami Sejati" mengarah pada sosok suami 'tulen' atau dalam bahasa Jawa: telah Dadi Wong. Dalam pengertian, suami memiliki peran yang seimbang baik dari sisi ekonomi (bekerja), modern (material), hingga harmonis (mengakui kekurangan dan membantu orang lain). Dengan kata lain, mengutip Permanadeli (2010: 61), Dadi Wong adalah paradigma cara hidup orang Jawa yang menurut kami memang berasal dari proses signifikasi atas kehidupan mereka ketika menghadapi lingkungannya.

Konotatif Etis. Berdasarkan pemaknaan secara perseptif dan kognitif di atas, dapat dibangun suatu pemaknaan konotatif etis bahwa Kecap ABC, melalui kampanye ini berupaya untuk memosisikan citra maskulin yang identik dengan konsep Dadi Wong atau suami sejati dalam budaya Jawa, di mana sosok suami menggambarkan beberapa parameter Dadi Wong, yaitu penghasilannya baik, (2) punya pekerjaan tetap (3) keluarganya harmonis, dan; (4) bisa bantu orang lain. Penghasilan yang baik tampak dari elemen fashion seperti kemeja, jam tangan, rumah, perabot rumah tangga yang merepresentasikan bahwa suami mampu memenuhi kebutuhan keluarga maupun kebutuhannya sendiri. Pemenuhan kebutuhan sendiri juga menggambarkan salah satu bagian dari Dadi Wong yaitu suami mampu membeli barang-barang modern seperti pakaian, jam tangan, tas kerja, untuk menunjang aktivitasnya di ruang publik, yang sekaligus menggambarkan pula kesadaran sosialnya sebagai laki-laki modern. Kemampuan untuk memenuhi kebutuhan pun menunjukkan bahwa sosok suami memiliki pekerjaan tetap dan stabil secara ekonomi.

Keluarga yang harmonis tampak dari ketiadaan gambaran situasi yang bersifat negatif, seperti kekerasan yang terjadi karena 
suatu konflik dalam rumah tangga. Suami digambarkan mampu menyelesaikan permasalahan dalam beban kerja dengan cara mengakui kesalahan dan dengan ikut membantu istri dalam memasak.

Suami sejati yang dapat berperan secara lengkap baik di ranah sosial maupun domestik juga disimbolkan melalui gambar yang dibuat oleh anak yaitu sosok superhero, di mana kekuatan menjadi unsur utama. Dalam pengertian, superhero ditampilkan sebagai kekuatan untuk melakukan sesuatu tanpa lelah, dan kekuatan-kekuatan lain yang bersifat internal seperti empati, emosi yang terkendali hingga cara berkomunikasi yang baik. Ketika sosok orang tua dapat memiliki unsur superhero, maka secara tidak langsung kekuatan itu akan diwariskan kepada anak. Ini menunjukkan bahwa apa yang terjadi di dalam kehidupan suami istri di rumah, akan berpengaruh pula terhadap sosok karakter anak.

\section{Analisis mitos maskulinitas pada konten dengan tema Akademi Suami Sejati}

Melalui analisis tanda denotatif dan konotatif di atas, dapat dilakukan analisis mitos mengenai maskulinitas pada kedua konten sebagai berikut: Pertama, konten menciptakan suatu mitos mengenai kesetaraan dalam rumah tangga, namun tanpa merendahkan citra maskulin. Pada kedua konten, tampak bahwa sosok suami selalu dicitrakan dengan penampilan yang baik, menawan, dan rapi, meskipun yang dilakukannya adalah memasak. Secara umum diketahui bahwa memasak seringkali menjadi pekerjaan yang banyak dibebankan kepada istri, dan meskipun istri juga seringkali ikut meningkatkan kesejahteraan ekonomi keluarga dengan bekerja, namun beban kerja dalam rumah tangga masih tetap ada pada pihak istri. Kecap ABC tampak berupaya untuk membalikkan persepsi bahwa pekerjaan rumah tangga juga dapat dilakukan oleh suami, meskipun secara umum, pekerjaan memasak seringkali dianggap sebagai aktivitas yang remeh temeh, banal, memalukan, dan tidak memberikan pengaruh terhadap perekonomian rumah tangga. Dalam hal ini dapat diasumsikan bahwa agar kampanye Akademi Suami Sejati dapat mempengaruhi audiens laki-laki, Kecap ABC menggambarkan sosok laki-laki/suami dalam aktivitas memasak dengan cara yang menyenangkan, menarik, dan tetap tampil menawan. Hal tersebut tampaknya dilakukan agar aktivitas memasak yang dilakukan oleh laki-laki bukan sesuatu yang akan merendahkan citra dirinya. Memasak, tampak seolah-olah dibuat seperti halnya seorang suami sedang bekerja, yang memerlukan perhatian khusus, keahlian khusus, passion, dan penting untuk dilakukan agar menciptakan keharmonisan dalam rumah tangga.

Kedua, kesejatian seorang suami dalam kampanye produk Kecap ABC identik dengan konsep Dadi Wong dalam budaya Jawa. Kecap ABC tampak menciptakan mitos bahwa suami sejati perlu memiliki kualitaskualitas yang mirip dengan Dadi Wong, antara lain berpenghasilan baik, memiliki pekerjaan tetap sehingga dapat menyejahterakan dan menciptakan keharmonisan keluarga, dapat membantu orang lain yaitu pekerjaan rumah tangga yang seringkali dilakukan oleh istri, tetapi juga tetap mempertahankan citranya sebagai lakilaki bergaya hidup modern.

\section{KESIMPULAN}

Melalui analisis yang telah dilakukan, dapat disimpulkan bahwa konten bertema 
Akademi Suami Sejati merupakan cara yang digunakan produk Kecap ABC untuk memengaruhi audiens melalui pendekatan pendidikan atau akademi, dengan mitos maskulinitas dan kesetaraan dalam rumah tangga sebagai big idea kampanye. Tema akademi sebagai pendekatan tampak bertujuan sebagai wadah bagi para suami untuk menjadi seorang suami sejati, dengan belajar memasak, baik secara mandiri maupun mengikuti acara yang diselenggarakan oleh Kecap ABC. Melalui berbagai kontennya di media sosial Instagram, audiens dapat mengikuti berbagai aktivitas dan kampanye untuk menjadi suami sejati versi Kecap ABC.

Dalam proses pemitosannya, Kecap ABC tampak melakukan komodifikasi suami dari kelas menengah ke atas untuk 'mewakili' sosok suami sejati; menawan secara penampilan, perekonomian yang baik, mampu menyelesaikan suatu permasalahan keluarga dengan baik. Citra tersebut secara umum dipahami sebagai sosok yang merepresentasikan konsep maskulin ideal di masyarakat. Dengan memanfaatkan hal tersebut, aktivitas seorang suami memasakyang seringkali dianggap pekerjaan seorang istri, tidak penting, dan bahkan memalukandapat terdistorsi.

Fenomena tersebut yang kemudian diambil oleh Kecap ABC dengan mengubah persepsi dan menciptakan mitos baru mengenai suami memasak. Memasak di rumah, menjadi menarik dan menyenangkan untuk dilakukan, dan tidak hanya akan menambah pengalaman baru bagi seorang suami, tetapi juga ikut melestarikan kesetaraan dalam rumah tangga. Aktivitas memasak juga diciptakan dengan cara yang lebih elegan, modern, dan tetap memperhatikan penampilan agar memasak menjadi baik dan penting untuk dilakukan. Dengan memasak di rumah, suami juga dapat menjadi teladan yang baik bagi anak-anak, dan anak pun akan menganggap sosok ayah bukan hanya sebagai kepala keluarga yang cakap dalam menyejahterakan, tetapi juga menciptakan keharmonisan rumah tangga.

\section{DAFTAR PUSTAKA}

\section{Buku}

[1] Aminuddin, (2008), Semantik. Pengantar Studi Tentang Makna, Bandung: Penerbit Sinar Baru Algensindo

[2] Barthes, Roland., (2009), Mitologi, Yogyakarta: Kreasi Wacana.

[3] Barthes, Roland., (2010), Membedah Mitos-mitos Budaya Massa, Yogyakarta: Jalasutra.

[4] Barthes, Roland., (2010), Imaji/Musik/Teks, Yogyakarta: Jalasutra.

[5] Bourdieu, Pierre., (2010), Dominasi Maskulin, Yogyakarta: Jalasutra.

[6] Creswell, John W., (2018), Penelitian Kualitatif \& Desain Riset. Memilih di antara Lima Pendekatan (Edisi ke-3), Yogyakarta: Pustaka Pelajar.

[7] Danesi, Marcel., (2010), Pesan, Tanda, dan Makna: Buku Teks Dasar Mengenai Semiotika dan Teori Komunikasi, Yogyakarta: Jalasutra.

[8] Herdiansyah, Haris., (2015), Wawancara, Observasi, dan Focus Groups Sebagai Instrumen Penggalian Data Kualitatif, Depok: PT RAJAGRAFINDO PERSADA.

[9] Illich, Ivan., (2007), Matinya Gender, Yogyakarta: Pustaka Pelajar

[10]Kotler, Philip., Kartajaya, Hermawan., Setiawan, Iwan., (2019), Marketing 4.0 Bergerak Dari Tradisional ke Digital, Jakarta: Penerbit PT Gramedia Pustaka Utama.

[11]Kuntowijoyo, (2019), Selamat Tinggal Mitos, Selamat Datang Realitas. Esai- 
Esai Politik dan Budaya, Yogyakarta: IRCiSoD

[12]Lister, Martin., dkk. (2009), New Media: a critical introduction. Second edition, NY: Routledge.

[13]Murniati, A. Nunuk. P., (2004), Getar Gender, Buku Pertama, Magelang: Yayasan Indonesia Tera.

[14]Nugroho, Riant. (2008), Gender dan Strategi Pengarus-utamaannya di Indonesia, Yogyakarta: Pustaka Pelajar.

[15]Permanadeli, Risa., (2015), Dadi Wong Wadon. Representasi Sosial Perempuan Jawa di Era Modern, Yogyakarta: Pustaka Ifada.

[16]Segal, Robert A., (2004), Myth. A Very Short Introduction, NY: Oxford University Press, Inc.

[17]Sobur, Alex., (2006), Semiotika Komunikasi, Bandung: PT Remaja Rosdakarya.

[18]Sugiyono, (2011), Metode Penelitian Kuantitatif, Kualitatif, dan $R \& D$, Bandung: Alfabeta.

[19]Suryajaya, Martin., (2016), Sejarah Estetika: Era Klasik Sampai Kontemporer, Yogyakarta: Indie Book Corner.

[20]Wolf, Naomi., (1997), Gegar Gender. Kekuasaan Perempuan Menjelang Abad 21, Yogyakarta: Pustaka Semesta Press.

\section{Jurnal}

[1] Hermawan, Fajar W., Mitos dan Relasi Kesadaran Masyarakat. Telaah atas Pembentukan Mitos Borjuasi Perancis Modern dalam Perspektif Roland Barthes, Jurnal Dharmasmrti Vol 15 No 28 2016, (https://ejournal.unhi.ac.id. Diakses September 2019)

\section{Situs Web}

[1] https://travel.kompas.com/read/2017/03/ 20/191000527/mengapa.baju.koki.berwa rna.putih 